Western University

Scholarship@Western

3-18-2013

\title{
Virtuosity On Virtu(e)osity and Theatrical Community
}

Kim Solga

The University of Western Ontario, ksolga@uwo.ca

Follow this and additional works at: https://ir.lib.uwo.ca/englishpub

Part of the English Language and Literature Commons

Citation of this paper:

Solga, Kim, "Virtuosity On Virtu(e)osity and Theatrical Community" (2013). Department of English Publications. 201.

https://ir.lib.uwo.ca/englishpub/201 


\title{
Virtuosity
}

\section{On Virtu(e)osity and Theatrical Community}

\author{
Kim Solga \\ School of English and Drama, Queen Mary, University of London, \\ k.solga@qmul.ac.uk
}

\section{Theatrical virtues, virtuoso pitfalls}

I never met David Bradby, and I did not know him well. Late in summer 2007 I sent him a manuscript at Contemporary Theatre Review, and he turned it around more quickly than I thought possible at an academic journal (and certainly in August): in less than a month I had two helpful readers' reports, a contract to publish, and David's aid in securing photos for the production I was discussing, Katie Mitchell's Iphigenia at Aulis (2004). The thing I remember most about the process of preparing that article is ease: David smoothed the way, creating what is still for me one of my most encouraging memories of academic publishing. He reminded me why we do what we do, and how to do it best.

Thus, when Dominic Johnson asked me to participate in this lexicon in honour of David, I was pleased to accept. I was also, however, somewhat flummoxed by my assigned term. 'Virtuosity' isn't something to which I give much thought; it's also not something I think of when I think back on my publishing experience with David. On the contrary: David struck me as a scholar and editor whose strength lay in shepherding others' good work - the work of scholars and artists - in the pages of 
CTR. I thought of him as supporting other, budding virtuosos (among the more mundane of us, of course).

Some time after I'd said yes to Dominic's commission, a helpful email came from the editorial team. Next to my name and my assigned term were appended some synonyms: craft, craftsmanship, celebrity. While these expanded my scope considerably, they didn't solve my problem. 'Celebrity' and 'virtuosity' make sense together in some contexts, but not in others. I think of Robert Lepage, Tony Kushner, Peter Brook, Laurence Olivier; curiously, I don't think of many women, and I think of very few artists of colour. Craft and virtuosity, too, are rather unlikely bedfellows: all virtuosos are crafts-persons, of course, but when I think of the virtuoso I think, almost immediately, of the impresario, the savant, the prodigy: of natural talent run wildly amok, rather than of hard work digging in the sand. Craft and virtuosity exhibit another tension, too: 'craft' has, for centuries, been figured in opposition to 'art', the domain of the virtuoso; I can think of quite a few virtuosic violinists, for example, but not that many virtuoso shipbuilders.

I was lost.

Lost scholars always have touchstones, of course; for me, that's the Oxford English Dictionary:

virtuosity, $\mathrm{n}$.

1.a. Manly qualities or character. Obs.

1.b. Virtuousness. Obs. (1721) 
2.a. The pursuits, interests, or temperament, characteristic of a virtuoso; interest or taste in the fine arts, esp. of a fastidious, finical, dilettante or trifling nature. (1673)

2.b. spec. Excessive attention to technique, or to the production of special effects, in vocal or instrumental music (also transf. in art or literature). (1865)

As I had suspected, virtuosity has long been associated with masculinity. Not expected, however: the eighteenth-century association of the term with virtue. Nor the foregrounding of the finicky! Although we have now lost this collision among the obsessive technicians, the prodigal (male) talents, and the agents of virtue, I began to wonder if this playing on words I was doing in an effort to find my footing might offer an excellent chance to reclaim past, and provocative, connections.

When I remember David Bradby, and the help he offered me early in my publishing career, I think much more quickly of virtue - of generosity of spirit, of the gifts of time and patience - than I do of the fastidious, the finicky, and the ferociously self-proud. When I think, in turn, of the artists I admire most right now, I think of these very same things. Some of the very best work around me here in Toronto is being created not by impresarios, but by artist-labourer-mentors who commit as much, if not more, of their time to collaboration and community-building as they do to acting, writing, directing, and creating. In the spirit of the virtues of non-virtuosity, I'd like to introduce you to two of these artists and the organizations they run. Perhaps not surprisingly, they are both women. 


\section{Tara Beagan and Native Earth Performing Arts (NEPA)}

Tara Beagan, the new Artistic Director of Native Earth Performing Arts, the oldest First Nations theatre company in North America, is a 'proud half breed':

Ntlaka'pamux (Thompson River Salish) on her mother's side and Irish-Canadian on her father's. In multicultural Canada, hapa identities are now bog-standard, but despite the rise in 'half-and-half' chic few part-indigenous Canadians will readily admit to their Native heritage. (In fact, as a result of decades of forced family separations and centuries previous of cultural genocide, many part-Natives don't even know of their indigenous backgrounds.) Beagan is different. She's political; she's outspoken; and she's committed to the challenges of living on the colour line. She began her playwriting career in 2004 with Thy Neighbour's Wife (UnSpun), which won the 2005 Dora Mavor Moore award for Outstanding New Play. Hot on the heels of that success, Dreary and Izzy became Beagan's first full-length work under the banner of Native Earth Performing Arts, an association that would prove lifechanging for her. She soon took a community liaison job in the NEPA office; shepherded by Yvette Nolan, the company's fierce and passionate former artistic director, Beagan fell in headfirst:

During my time inside NEPA's office, I wrote my first commission and I was handed my first dramaturgical gig. The playwright was thirty years my senior. I was terrified. I did not know why I was being trusted to contribute to his growth 
in some way. Yvette was convinced that I could do the job. Her faith helped me find my way. ${ }^{1}$

In a recent memoir, Beagan reflects candidly on her years working with Nolan at Native Earth, a company devoted to celebrating and strengthening young artists. She is hard on herself as she remembers the moments she failed at compassion, and especially as she recalls forgetting or dismissing the logic and the stakes of Nolan's mentorship of her. She also, in turn, takes seriously the responsibility of becoming a mentor to the generation of First Nations playwrights emerging behind her. Beagan's labour, as an actor, as a playwright, and now as an artistic director, cleaves to and is sustained by the belief that artists - especially First Nations artists - in Canada have an urgent mandate to support one another, to enable one another's work, and together to build communities. During a recent lunch, she spoke with me about finding her feet in NEPA's top job. With respect, she looks back on all that Nolan has built, but she also sees room for positive change for the community now emerging. In particular, she hopes to draw - ironically for me here, perhaps - on the celebrity of several of Canada's top First Nations performers in order to sell the power and the passion of NEPA's new work as mainstream theatrical labour, not simply as the work of 'others' on 'margins'.

Beagan is something of a committed realist. She wants the artists in her stable to be seen as real: not as just 'good enough' for 'Native artists', and not, under any circumstances, as disposable, as barely qualified, as higher-brow versions of the vicious, degrading stereotypes that still, in 2011, plague so many First Nations 
citizens of multicultural Canada. As a playwright, Beagan is perhaps best known for two recent works: The Mill: The Woods (2010), part of a linked cycle of plays commissioned by Toronto's TheatreFront, and Miss Julie: Sheh'mah (2008), an adaptation of Strindberg's classic naturalist text, commissioned by Toronto's KICK Theatre and set among Ntlaka'pamux servants in the interior of British Columbia in 1929. In both plays, but especially in Sheh 'mah, ${ }^{2}$ Beagan uses the often-maligned tenets of classical realist dramaturgy to send a very contemporary, very political message to audiences: that the First Nations characters on her stage are real people. They are not symbols or ciphers; they are not stereotypes; and they are not to be approached and handled with politically correct caution. Above all, they are not - as so many of their 'real life' kin have been, and shamefully still are, in Canada - a version of homo sacer, of bare life, expendable life, abjectable life. When Johnnie, Beagan's version of Strindberg's Jean, makes love to the white, colonial Julie in full view of the audience (for an extended period of time: 10 uncomfortable minutes), both characters give and receive real, genuine pleasure. This, Beagan insists, is a glimpse of what could be in a Canada devoted more fully to social justice for its First peoples; our legislative realities had better catch up, and quick.

\section{Jennifer H. Capraru and Isôko: The Theatre Source}

Jennifer Capraru has been working in Rwanda, with East African artists of all abilities and backgrounds, since joining the crew of the documentary, Shake Hands With the Devil, in 2006. Raised in Montreal and now based in Toronto, Capraru is the Artistic Director of Theatre Isôko (http://www.isoko-rwanda.org/), a not-for-profit NGO she

2 The term means 'white trash' in the language of the Thompson River Salish. 
established in order to support her all-Kinyarwanda-language production of Colleen Wagner's award winning 1995 genocide play, The Monument. This production began on a shoestring, in found spaces, with no money, and with actors lost (continuously) and found (less often), in Kigali in 2007; designed to generate for Rwandan artists the opportunity to share their experiences of that country's 1994 genocide within a contemporary dramaturgical framework, it has since toured to Butare, Rwanda's second-largest city, as well as throughout rural Rwanda, and to Toronto, Montreal, and Ottawa. Along the way, Capraru has sought to create opportunities for Rwandan artists (both brand new, and otherwise trained) not only to learn the craft of contemporary theatre, still very new in Rwanda, but also to earn a living wage from their art.3

I saw The Monument at Toronto's World Stage festival on 1 May 2011 and have since begun working with Capraru on an article about it. The production reflects in several ways Capraru's generous, generative practice as a director and as a mentor, and especially her commitment to helping her artists build an international profile. Capraru insisted the show be staged in the Harbourfront Centre's Brigantine Room, an intimate space that was configured in the round in order to preserve the challenge to witness that the actors perform as they bring to the stage, with pride and also with real struggle, a version of their own stories of survival. The terms she negotiated with the festival ensured that everyone on the cast and crew would be paid the same, competitive salary for both rehearsal and run periods, and guaranteed that the cast would have hotel accommodations paid by World Stage for the duration of its labour

\footnotetext{
3 In an unpublished interview recorded in 2011, Jean Paul Uwayezu, who plays Stetko in Monument, argues that Isôko's difference from other, emerging theatre companies in Kigali is its commitment to working with at least one brand-new actor on each show, training him or her along the way. Actors are paid Canadian equity minimums whenever possible; for Uwayezu and his colleagues during the original development of Monument, that amounted to US\$200 per week.
} 
in Toronto. She arranged question-and-answer sessions after every show, allowing audiences to engage in direct discussions with the actors about the evolution of the production and the social imperatives of their work. (At the cast's request, Capraru fielded all question about cast and crew ethnicities. While the team was comprised of both Hutus and Tutsis, no member ever revealed his or her origin.) She also ensured that space was made in the theatre after every show for actors Jaqueline Umubyeyi (Mejra), Solange Liza Umuhire (Ana), and Ruth Nirere (Ini) - established musicians in their own right - to sell merchandise associated with their own, independent art. Perhaps most crucially, the mentorship Capraru has offered her actors all along the way is evident in the outstanding work they presented each night on tour: neither Umubyeyi nor Jean Paul Uwayezu, the leads who carry this 90-minute two-hander, had ever acted before meeting Capraru.

I realize as I write the above that Capraru may sound a bit like the white woman who went to Africa to bring out the best in the locals. I want to dispel this notion. Capraru is no virtuoso; she is no 'intercultural' impresario. She is both aware of, and actively works to resist, the colonial impulses inherent in her position at Isôko. She speaks with humility about, and especially in front of, her actors. She readily admits - to me, to them, and to the press - how little she knows, even today, about what they have brought with such force to their shared stage. When things get rough, she consoles them, but they also console and support her. Her role in The Monument, and at Isôko more broadly, is, like Beagan's at NEPA, less as 'director' than as facilitator, enabler, or community builder.

Long may their non-virtuosity reign. 
